\title{
食品中のブドウ球菌エンテロトキシン 検出法に関する研究
}

\section{CM-Sephadex パッチ法イオン交換の導入}

(昭和 47 年 9 月 11 日受理)

\author{
Detection of Staphylococcal Enterotoxins in Foods \\ I. Application of Batch Operation on CM-Sephadex Ion Exchanger \\ Yoshiaki HARADA \\ (Substation in Yokohama Quarantine Station, Food Sanitary Section, Ministry \\ of Health and Welfare: Shinko-cho, Naka-ku, Yokohama)
}

原田 禎 顕*

\begin{abstract}
Procedures were developed for assay of staphylococcal enterotoxins in foods, using microslide gel double diffusion test.

(1) Foods were prepared for assay by addition of water (homogenization or mashing in case of cereal foods) adjustment of $\mathrm{pH}$ to 7.4-7.6, blending, and centrifugation. The supernatant fluids were then adjusted to $\mathrm{pH} 4.5$ (in case of animal foods) or $\mathrm{pH} 6.0$, and centrifuged. Supernatant fluids taken at $\mathrm{pH} 4.5$ were readjusted to $\mathrm{pH} 6.0$, and centrifuged. From these supernatant fluids, enterotoxins were partially purified by adsorption on CMSephadex C-50 equilibrated with $0.01 \mathrm{M}$ sodium phosphate (pH6.0), washing with $0.01 \mathrm{M}$ sodium phosphate ( $\mathrm{pH} 6.0$ ), then eluted with $0.2 \mathrm{M}$ sodium chloride in $0.1 \mathrm{M}$ sodium phosphate (pH 7.6), and concentrated by dialysis against polyethylene glycol.

Adequate dosage levels of $\mathrm{CM}$-Sephadex in the batch ion exchange for various foods were determined, individually.

(2) By these procedures, enterotoxins were detected in 12 out of 16 foods suspected for cause of poisoning outbreaks. Enterotoxin A (50\%) and A+D (33\%) were predominant types. Concentrations of enterotoxins detected in foods were ranging up to $0.3 \mu \mathrm{g} / \mathrm{g}$, and estimated at $0.05 \mu \mathrm{g} / \mathrm{g}$ on the average. In 4 outbreaks, neither enterotoxins nor enterotoxinproducing staphylococci were isolated from the suspected foods.

(3) The extract from suspected cream puff containg $4.5 \mu \mathrm{g}$ of enterotoxin A induced emetic responses in a volunteer by feeding test.
\end{abstract}

(Received September 11, 1972)

\section{站 豆}

食品中のブドウ球菌エンテロトキシン（以下 Ent と略 す）を抽出してゲル内沈降反応で検出する方法について は，多数の報告があるが，通常の食中毒原因食にみられ ろ微量の Ent の検出には，イオン交換体を使用した高

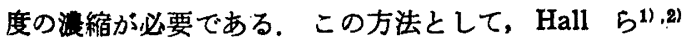
は, pH 6.2 6.4 に調整した Amberlite CG50のカラム クロマトグラフィーを用い, 試料に添加した Ent A を

*厚生省食品衛生棵 横浜検疫所趽在：横浜市中区 新港町
$27 \%$, Ent B を $42 \%$ 回収することに成功し, 18 検体 の食中毒容疑食品中 6 検体に Ent を検出した。これと 前後 L, Casman 58) (4) $0.01 \mathrm{M}$ リン酸緩㣫液, $\mathrm{pH} 6.0$ に調整した CM-cellulose (CM 70) カラムクロ マトグラフィーにより, Ent A を 9 80\%, Ent B を 17.5 72\% 回収しており，4 例の食中毒原因食品に Ent A を検出した。 この方法は, 後に Zehren ら゙によりチ 一ズで 16 35\%, 国田ら $\%$ の Ent A 回収率が得られている。 また, Ent C の 吸着を促進するため $0.005 \mathrm{M}$ リン酸緩衝液, $\mathrm{pH} 5.7$ K 
調整した CM-cellulose (CM 22) カラムを用いるよう改 められた7),81.

このカラム法イオン交換の適用は, 食品の種類によっ て難易があり，特別な前処理を施さなければ流下すら困 難な場合も多い，それゆ之，回收率の改善之同時に，前 処理法の確立が今後の課題と思われる。

著者》〜111は, 初め乳に拉ける Ent の抽出法を検討し てきたが，前報12) では rennet 処理, Sephadex G-25ゲ ルろ過，CM-Sephadex C-50 (以下 CMS と略す) カラ ムクロマトグラフィー, polyethyleneglycolによる濃縮 等の手順で, Ent を抽出できると報告した。この研究に イオン交換容量の大きいCMS を選んだのは，食品成分 の干涉による Ent の回収率の低下をカパーするためで あった。この方法を軸に，さらに簡略化と適用食品の種 類を広げる工夫を試みたところ，イオン交換をバッチ法 で実施することにより, 前述のカラム法での障害を除く ことができ，能率よく抽出を進め得ることを知った。 そ れゆえ，本報では，食品中の Entをバッチ法で抽出す るに必要な諸条件を，人為的にEntを添加した試料およ び実際の食中毒推定原因食品等を用いて検討したので, その結果を報告する。

\section{実験材料と方法}

免疫血清と毒素：主として米国 Wisconsin 大学の M. S. Bergdoll 博士分与の Ent antiserum A (A-48-

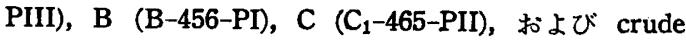
Ent A (IW 168.173 A 100), B (IW 180 B S-6), C (IW 17 B B-137) を用いた。 また，食中毒事件試料 の検索には, 米国 FDA の故 E.P. Casman 博士ら分 与の anti D serum および reference Ent D を追加使 用した。 その他， $196 \mathrm{E} ，$ S-6, 137 の各ブドウ球菌菌株

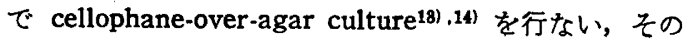
濃縮遠心上清を模擬試料の調製に用いた。

Ent antiserum A, B, C は, micro-Ouchterlony 法 ではそれぞれ $1: 20,1: 100,1: 50$ に希釈し，Oudin 法では終末濃度がそれぞれ $1: 25,1: 100,1: 50$ にな るよらに希釈して使用した。 また， micro-Ouchterlony 法の reference Ent の濃度は $1 \mu \mathrm{g} / \mathrm{ml}$ とし， $0.37 \%$ の 割にブレインハートインフュージョンブイョン培地“栄 研”を添加した生理食塩水の溶液とした。

血清反応: micro-Ouchterlony 法扰よび Oudin 法 によるゲル内沈降反応によった。

micro-Ouchterlony 法は, Crowle ${ }^{15)} と$ Casman $5^{16)}$ の 2 つの方法で実施した．前者は Ent A, B, C の試験 に用いることとし $5^{\circ}$ で $48 \pm 4$ 時間反応後, 後者は主 として Ent D の試験に用いることとし室温で 3 日間反 応後，それぞれ染色して顕微鏡用の人工光線をあて黒色 板をバックに沈降線を観察した。ただし，染色は原法に よらず, template をはがしたスライド表面を水洗し， 後者ではそのまま，前者ではさらに $0.03 \mathrm{M}$ リン酸緩衝
液, $\mathrm{pH} 7.4$ に一夜漫した後, 直接 $0.1 \%$ azocarmin G

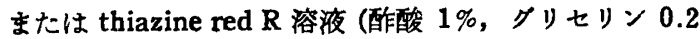
\%)に 10 分間漫してこれに代えた。

抗原の希釈1，18)には，液状食品または固型食品のスラ リーを $\mathrm{pH} 4.5$ および $\mathrm{pH} 6.0$ で遠心分離して沈殷物 を除去して得た上清（以下酸処理上清と呼ぶ）を用いる か, $0.37 \%$ の割にブレインハートインフュージョンブイ ヨン培地を添加した生理食塩水を用いた。

Ent の同定は reference line との coalescence によ った.

定量は通常 micro-Ouchterlony 法によったが，添加 Ent の抽出処理後の浱度を測定する際は, 被検液を算術 級数的または幾何級数的に連続希积して反応を行ない， 沈降線が認められる最高の希釈倍数を添加 Ent のそれ と比較して算出した。 この連続希釈の最大間隔は 12 $25 \%$ であった．食中毒事件試料の Ent 濃度を測定する 際は, 沈降線の認められる最小浱度を, Ent A, B, C で はいずれも $0.3 \mu \mathrm{g} / \mathrm{ml}$ (著者成續), Ent D では $0.4 \mu \mathrm{g}$ / $\mathrm{ml}\left(\right.$ Zehren $5^{5)}$ ) とみなして計算した.

Oudin 法は, 一部の定量にのみ使用し, micro-Ouchterlony 法と併用した。術式は Read 517) と同様にした が, 抗原の希釈は $0.01 \%$ の割にチメロサールを添加し た $0.2 \%$ ブレインハートインフュージョンブイョン培地 水溶夜で行なった。検量線は，Ent A, B, Cを 80, 40, $20,10,5$ および $2.5 \mu \mathrm{g} / \mathrm{ml}$ に希釈して反応を行ない， Ent 濃度の対数を緃軸に, migration 距離を横軸にとり プロットして作製した。

供試食品: 初め抽出の方法と条件を決定するため, 牛乳, 加工乳, 脱脂粉乳, シュークリーム (5 銘柄), らぐいす豆 (ばら売り 4 銘柄， ポリ詰め 2 銘柄)，かま ぼこ（3 銘柄， 5 種)，ブレス八ム ( 1 種)，おおぎ，お。 にぎりごはん等を選び，これに一定量の Entを加え て実験材料とした。. 添加方法については成績で述べる.

その他，食中毒推定原因食品および容疑食品も供試し た.この場合は食品中に含まれる Ent の検出のほか, スタフィロコッカス培地 110 または食塩卵寒天培地によ る菌数の測定と, 分離菌のマンニット分解能, $7.5 \%$ 食 塩耐性, コフグラーゼ産生能, Casman 5 ${ }^{18)}$ の方法によ る Ent 産生能等についても試験した。

食品中の Ent 抽出法： 概要は Fig. 1 のとおりであ る.

固型食品は，初め蒸留水を加えてホモジナイザーにか け均質化するか，乳鉢で十分すりつぶしたものを作るが、 一部の試験ではさらにこれに $0.2 \mathrm{M}$ 灌度の割に食塩を添 加した。これらのスラリーを $\mathrm{pH} 7.5$ に修正し，容量を 原食品重量の 4 または 5 倍に補正し，5分間強く筧拌し た.

ついで,一部のものはそのまま, 他のものは不溶物を 遠心除去した後, $\mathrm{pH} 4.5$ または $\mathrm{pH} 6.0$ に修正し, 析 


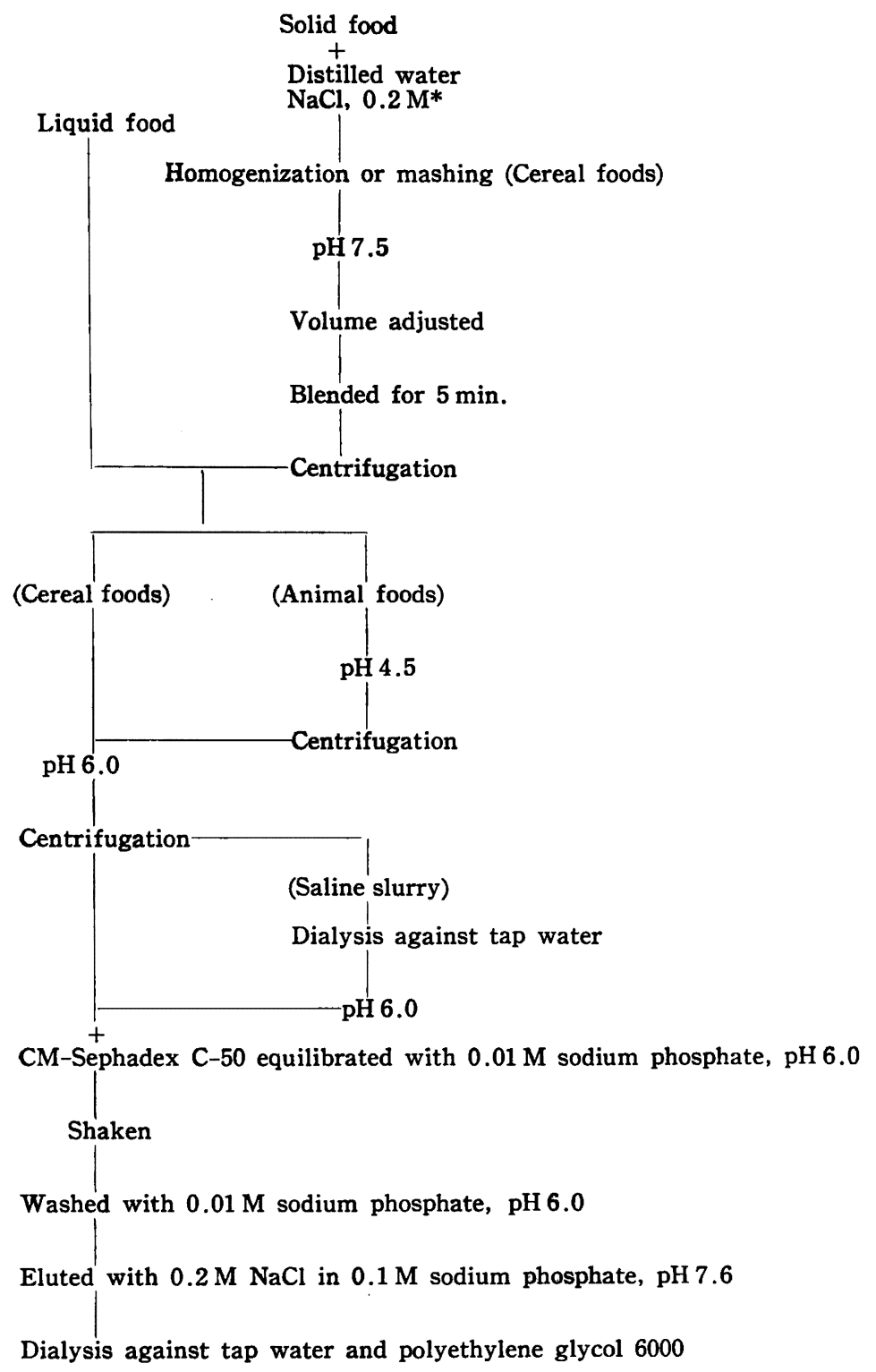

Fig. 1. Extraction of enterotoxins by use of CM-Sephadex

* usually omitted

出する不溶物を遠心除去した。 このらち $\mathrm{pH} 4.5$ で処理 したものはさらに pH 6.0 に修正し，再び遠心分離を行 ない析出物を除去した.

粉乳では重量の 5 倍容の水溶液とし，牛乳ではそのま ま用い, $\mathrm{pH} 4.5$ ついで $\mathrm{pH} 6.0$ で遠心分離して析出物 を沈股除去した。

このようにして得られた $\mathrm{pH} 6.0$ の遠心上清の一定量 をイオン交換に付するのであるが，食塩を添加したスラ
リーから調製したものは，あらかじめ $3 \sim 4$ 時間流水透

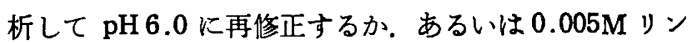
酸緩衝夜 (pH 6.0) で 20 倍に希瀵し，イオン強度を下 げて使用することにした。

これらの $\mathrm{pH} 6.0$ の上清にあらかじめ $0.01 \mathrm{M}$ リン酸 緩衝液， pH6.0 で平衡にした CMS を加え，約 30 分 間，随時振とうして Ent を吸着させ，ついで夜分を除 去し， $\mathrm{CMS}$ を $0.01 \mathrm{M}$ リン酸䌅衝液， $\mathrm{pH} 6.0$ で洗浄 


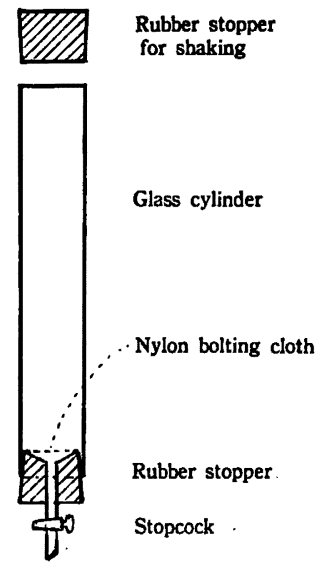

Fig. 2. Batch-operation apparatus in which shaking, filtration, washing and elution were performed

した.この洗浄は, 通常 CMS 0.1 g につき毎回 $4 \mathrm{ml}$ の 割で 5 回行ならこととしたが，上清が無色透明にならな い場合はさらに洗浄を反䧻した。ついで $0.2 \mathrm{M}$ 濃度の割 に食塩を添加した $0.1 \mathrm{M}$ リン酸緩衝液, $\mathrm{pH} 7.6$ で Ent を溶出したが，この溶出は CMS $0.1 \mathrm{~g}$ につき毎回 $4 \mathrm{ml}$ の割で 3 回以上，通常 4 回反㠅した。これらの溶出液は 口紙でろ過し，セロフォンチューブにパックして流水透
析 3 時間後, polyethylene glycol 6,000をふりかけ50 で 浱縮した。ついでチューブ内の濃縮液を取り出し，千ュ ーブ内を少量の $0.03 \mathrm{M}$ リン酸緩衝液, $\mathrm{pH} 7.4$ で 3 回ゆ すいだ洗液と合わせ,遠心分離して沈殿物を除去しっこの 上清を再び同様にして濃縮したものを血清反応用被検液 とした.なおこの被検液の食品に対する濃縮度は, “固 型食品のスラリーおよび液状食品の Ent 濃度は, その 酸処理上清中の Ent 濃度と等しい”として算出した.

これらの処理を通じ， $\mathrm{pH}$ の修正は $85 \%$ リン酸およ び $1 \mathrm{~N}$ 水酸化ナトリウムで行ない，遠心分離は 10,000 〜12,000 rpm, 10 分とした。 また CMS 吸着以後の液 相の除去, 洗浄, 溶出等の処理は, 口紙または nylon bolting cloth (NXX 25; $196 \times 238$ meshes per lineal inch) を通すことにし，不本意な CMS の排除や迷入に よるEntの損失を防いた。，紙は基礎実験のみに用い たが，酸性時における Ent の口紙への吸着を考虑し， 溶出まで同一口紙上で処理することにした， bolting cloth を用いる時は, Fig. 2 のように漏斗状に削ったュ ック付きのゴム栓上に bolting clothを張り, ガラス管 にはめ込んだ装置を作り, 洗浄, 溶出の一連の処理をこ の中で進めた.

\section{実験成耤}

\section{CMS パッチ処理と Ent の吸着}

初め, シュークリームに蒸留水を加え 4 倍容に補正し て作ったスラリーの酸処理上清に crude Ent B $1 \mu \mathrm{g} /$

Table 1. Recovery of Enterotoxin B from Food Supernatant Fluids by Use of CM-Sephadex

\begin{tabular}{|c|c|c|c|c|c|c|c|c|}
\hline \multirow{2}{*}{$\begin{array}{l}\text { Supernatant fluid } \\
\text { extracted from } \\
\text { (dilution) }\end{array}$} & \multicolumn{8}{|c|}{ Total food solids (approx.g)/g of CM-Sephadex } \\
\hline & 6 & 8 & 10 & 12 & 14 & 16 & 18 & 20 \\
\hline $\begin{array}{l}\text { Milk } \\
\text { ml/g of CM-Sephadex } \\
\text { per cent recovery }\end{array}$ & $\begin{array}{c}52.6 \\
100\end{array}$ & $\begin{array}{c}70.2 \\
100\end{array}$ & $\begin{array}{c}85.3 \\
100\end{array}$ & $\begin{array}{r}102 \\
90\end{array}$ & $\begin{array}{r}119 \\
78\end{array}$ & $\begin{array}{r}137 \\
78\end{array}$ & $\begin{array}{r}154 \\
78\end{array}$ & \\
\hline $\begin{array}{l}\text { Dry Skimmilk Powder (5-fold) } \\
\mathrm{ml} / \mathrm{g} \text { of CM-Sephadex } \\
\text { per cent recovery }\end{array}$ & $\begin{array}{c}31.3 \\
100\end{array}$ & & $\begin{array}{c}52.2 \\
100\end{array}$ & $\begin{array}{c}62.7 \\
88\end{array}$ & $\begin{array}{c}73.0 \\
75\end{array}$ & & & \\
\hline $\begin{array}{l}\text { Cream puff (4-fold) } \\
\mathrm{ml} / \mathrm{g} \text { of } \mathrm{CM} \text {-Sephadex } \\
\text { per cent recovery }\end{array}$ & $\begin{array}{l}57.8 \\
100\end{array}$ & $\begin{array}{c}77.0 \\
100\end{array}$ & $\begin{array}{c}96.2 \\
100\end{array}$ & $\begin{array}{l}115 \\
100\end{array}$ & $\begin{array}{l}135 \\
100\end{array}$ & $\begin{array}{l}154 \\
100\end{array}$ & $\begin{array}{l}173 \\
100\end{array}$ & $\begin{array}{l}192 \\
100\end{array}$ \\
\hline $\begin{array}{l}\text { UGUISUMAME } * 1 \text { (4-fold) } \\
\mathrm{ml} / \mathrm{g} \text { of CM-Sephadex } \\
\text { per cent recovery }\end{array}$ & & & & $\begin{array}{c}71.3 \\
100\end{array}$ & $\begin{array}{c}83.2 \\
100\end{array}$ & $\begin{array}{c}95.0 \\
100\end{array}$ & $\begin{array}{l}107 \\
100\end{array}$ & $\begin{array}{l}119 \\
100\end{array}$ \\
\hline $\begin{array}{l}\text { Ham (4-fold) } \\
\mathrm{ml} / \mathrm{g} \text { of CM-Sephadex } \\
\text { per cent recovery }\end{array}$ & & $\begin{array}{c}78.3 \\
100\end{array}$ & $\begin{array}{c}97.8 \\
100\end{array}$ & $\begin{array}{l}117 \\
100\end{array}$ & $\begin{array}{l}137 \\
100\end{array}$ & $\begin{array}{r}156 \\
90\end{array}$ & $\begin{array}{r}176 \\
80\end{array}$ & $\begin{array}{r}195 \\
74\end{array}$ \\
\hline $\begin{array}{l}\text { KAMABOKO } * 2 \text { (4-fold) } \\
\mathrm{ml} / \mathrm{g} \text { of CM-Sephadex } \\
\text { per cent recovery }\end{array}$ & & & $\begin{array}{l}140 \\
100\end{array}$ & $\begin{array}{l}168 \\
100\end{array}$ & $\begin{array}{r}197 \\
74\end{array}$ & $\begin{array}{r}225 \\
67\end{array}$ & $\begin{array}{r}253 \\
57\end{array}$ & $\begin{array}{r}281 \\
50\end{array}$ \\
\hline
\end{tabular}

*1 Sugared green peas

*2 Japanese-style fish cake 
$\mathrm{ml}$ の割に添加し，この 20, 40 および $80 \mathrm{ml}$ に CMS を $1 \mathrm{~g}$ あて加えて振とうしたところ，その遗心上清はい ずれも $1 / 3$ 容に漫縮しても micro-Ouchterlony 法で Ent が検出されなくなった。一方, CMS から 0.2M 食 塩添加の 0.1M リン酸楥衝液, pH7.6で溶出した液は 強力な Ent の沈降線を生ずることを認めた，それゆえ， さらに詳細に Ent を抽出するに必要な CMS 量を調べ ることにした.

\section{CMS 使用車と Ent B 回収柬}

牛乳, 粉乳 5 倍水溶液, および 4 倍容に水で補正作製 したシュークリーム，らぐいす豆，八ム，かまぼこ等の スラリーの各酸処理上清に crude Ent B を $1 \mu \mathrm{g} / \mathrm{ml}$ の 割に加えこえれ CMS を種々の割合に添加して Ent を抽出し， micro-Ouchterlony 法で反応を行ない，抽出 前の加毒酸処理上清の反応と比較し, Ent の回収率を測 定した。その結果は Table 1 のとおりであった。すな わち, CMS $1 \mathrm{~g}$ につき牛乳では $85.3 \mathrm{ml}$, 粉乳では 52.2 $\mathrm{ml}$, ハムでは $137 \mathrm{ml}$, かまほこでは $168 \mathrm{ml}$ 以下の酸処 理上清を処理する際はほぼ完全に Entを回収できるが, これを越えると回收率が著明に低下した。シュークリー

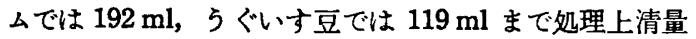
を增してもなおほぼ100\% の回収率が得られた。

\section{CMS 使用早の決定}

前実験成績を参考にして, 同酸処理上清に crude Ent $\mathrm{A}, \mathrm{B}, \mathrm{C}$ をそれぞれ $1 \mu \mathrm{g} / \mathrm{ml}$, 計 $3 \mu \mathrm{g} / \mathrm{ml}$ あて添加し,
同様にして回収率を測定した。その結果は Table 2 の とおりで, Ent の型により回収様相が異なるが，3型 の Ent がともにほぼ完全に回収される最大の酸処理上 清量は, CMS $1 \mathrm{~g}$ につき牛乳および加工乳では大約 80 $\mathrm{ml}$, 粉乳では $35 \mathrm{ml}$ ，八ムでは $120 \mathrm{ml}$ ，かまぼこでは $120 \mathrm{ml}$ で,シュークリームおよびうぐいす豆では $240 \mathrm{ml}$ まで増量してもなお完全な回収が得られた。

以上の実験でパッチ法によっても一定量以上の CMS を使用すればほぼ完全に含有 Ent を捕集できることが 明らかになったので，つぎにこの方法でイオン交換を行 ならために最低限必要な食品成分の除去条件を検討し た。

\section{食品不溶物の除去 pH と上清中の Ent 瀿度}

牛乳, 粉乳 5 倍水溶液, および 4 倍容に水で補正作製 したシュークリーム，らぐいす豆，かまぼこ等のスラリ ーに crude Ent A, B, C を 5 または $1.5 \mu \mathrm{g} / \mathrm{ml}$ の割に 加え， pH 4.5 に修正して遠心分離を行ない，その上清 を pH6.0に修正して再び遠心分離した上清の Ent 濃 度を添加 Ent 濃度と比較した。この試験に扮ける Ent の定量は, 牛乳, 粉乳およびかまぼこの試液では microOuchterlony 法と Oudin 法の両者で実施し, シューク リームおよびうぐいす豆の試液では micro-Ouchterlony 法のみで実施した，対照はそれぞれの食品の酸処理上清 に Ent を一定量添加した溶液とした。

その結果は Table 3 のとおりで, 牛乳, 粉乳, シュ

Table 2. Recovery of Enterotoxins A, B and C from Food Supernatant Fluids by Use of CM-Sephadex

\begin{tabular}{|c|c|c|c|c|}
\hline \multirow{2}{*}{$\begin{array}{l}\text { Supernatant fluid } \\
\text { extracted from }\end{array}$} & \multirow{2}{*}{$\begin{array}{l}\mathrm{ml} \text { of supernatant fluid } \\
\text { per } \mathrm{g} \text { of } \mathrm{CM} \text {-Sephadex }\end{array}$} & \multicolumn{3}{|c|}{ Recovery rate (\%) } \\
\hline & & Enterotoxin A & Enterotoxin B & Enterotoxin C \\
\hline Milk & $\begin{array}{r}60 \\
80 \\
100\end{array}$ & $\begin{array}{r}100 \\
100 \\
67\end{array}$ & $\begin{array}{l}100 \\
100 \\
100\end{array}$ & $\begin{array}{r}100 \\
100 \\
75\end{array}$ \\
\hline Enriched milk & 80 & 100 & 100 & 100 \\
\hline $\begin{array}{l}\text { Skimmilk } \\
\text { (5-fold diluted) }\end{array}$ & $\begin{array}{l}35 \\
40\end{array}$ & $\begin{array}{r}100 \\
83\end{array}$ & $\begin{array}{l}100 \\
100\end{array}$ & $\begin{array}{r}100 \\
83\end{array}$ \\
\hline $\begin{array}{l}\text { Cream puff (cream only) } \\
\text { (4-fold diluted) }\end{array}$ & $\begin{array}{l}200 \\
240\end{array}$ & 100 & $\begin{array}{c}(100) \\
100\end{array}$ & 100 \\
\hline $\begin{array}{l}\text { UGUISUMAME (in bulk) } \\
\text { (4-fold diluted) }\end{array}$ & $\begin{array}{l}200 \\
240\end{array}$ & 100 & $\begin{array}{c}(100) \\
100\end{array}$ & 100 \\
\hline $\begin{array}{l}\text { UGUISUMAME (vacuum-packed) } \\
\text { (4-fold diluted) }\end{array}$ & $\begin{array}{l}200 \\
240\end{array}$ & $\begin{array}{l}100 \\
100\end{array}$ & $\begin{array}{l}100 \\
100\end{array}$ & $\begin{array}{l}100 \\
100\end{array}$ \\
\hline $\begin{array}{l}\text { Pressed ham } \\
\text { (4-fold diluted) }\end{array}$ & $\begin{array}{l}120 \\
140 \\
160\end{array}$ & $\begin{array}{r}100 \\
71 \\
<60\end{array}$ & $\begin{array}{l}100 \\
100 \\
100\end{array}$ & $\begin{array}{r}100 \\
75 \\
50\end{array}$ \\
\hline $\begin{array}{l}\text { KAMABOKO } \\
\text { (4-fold diluted) }\end{array}$ & $\begin{array}{l}120 \\
140 \\
160 \\
160\end{array}$ & $\begin{array}{r}100 \\
83 \\
56\end{array}$ & $\begin{array}{l}100 \\
100 \\
100 \\
(100)\end{array}$ & $\begin{array}{r}100 \\
100 \\
75\end{array}$ \\
\hline
\end{tabular}


Table 3. Recovered Enterotoxins A, B and C in the Supernatant Fluid of Food or Food Slurry Prepared by Successive Centrifugations at $\mathrm{pH} 4.5$ and then at $\mathrm{pH} 6.0$

\begin{tabular}{c|c|c|c} 
Food & \multicolumn{2}{|c}{ Recovery rate (\%) } \\
\cline { 2 - 4 } & Enterotoxin A & Enterotoxin B & Enterotoxin C \\
\hline Milk & 100 & 100 & 100 \\
\hline Skim milk powder & 100 & 100 & 100 \\
\hline Cream of cream puff (F) & (A) & 100 & 100 \\
\hline UGUISUMAME(S) & 100 & $<6$ \\
\hline KAMABOKO (K-1) \\
(K-2)
\end{tabular}

ークリームおよびかまぼこでは試料に添加した Ent 濃度と遠心処理後の Ent 濃度との間に差が認められな かった. これに反し，5ぐいす豆では，Ent C の回収率 は $67 \%$ 以下であった。 またこの Ent A の検出濃度 は添加 Ent 濃度の $133 \%$ とい5例外的な成績が得ら れたが，その原因は追求しなかった。

この実験で一部の食品に共沈が関与してくることが明 らかになったので, 次にその出現状況につき詳細に検討 することにした。

\section{共沈現象の検討}

シュークリームの場合: クリームを用いる場合と全 体を用いる場合とでは異なった成績が得られる可能性が ある. それゆえ， 3 銘柄のシュークリームを用いてこの 両者の蒸留水でのスラリーを作り, Ent C が $1.5 \mu \mathrm{g} / \mathrm{ml}$ になるように濃縮培養上清を加え, $\mathrm{pH} 7.4$ で遠心分離 した上清，および $\mathrm{pH} 4.5$ で遠心分離した上清を $\mathrm{pH} 6.0$ で再び遼心分離した上清の両 Ent 濃度を, 添加 Ent 濃 度と比較した。 その結果は Table 4 のとおりであった。

Table 4. Recovered Enterotoxin $C$ in the Supernatant Fluid of Food Slurry Prepared by Successive Centrifugations at $\mathrm{pH} 4.5$ and 6.0 and again at $\mathrm{pH} 7.4$

\begin{tabular}{c|c|c|c} 
Cream puff & & \multicolumn{2}{|c}{ Recovery rate (\%) } \\
\hline Maker & Sample & $\mathrm{pH} \mathrm{4.5-6.0}$ & $\mathrm{pH} \mathrm{7.4}$ \\
\hline \multirow{2}{*}{ (H) } & Whole & 100 & 80 \\
& Cream & 100 & 87 \\
\hline (F) & Whole & 100 & 93 \\
& Cream & 100 & 73 \\
\hline (M) & Whole & 100 & 100 \\
& Cream & 100 & 100
\end{tabular}

すなわち, クリームで作ったスラリーでも, 全体で作っ たスラリーでも，ほぼ同様な成績が得られ，pH 4.5 拉 よび $\mathrm{pH} 6.0$ で遠心分離した上清中の Ent 濃度は対照 とよく一致する成績が得られた。 pH 7.4 で遠心分離し た上清中の Ent 濃度は, 対照と同程度ないしやや低く, $100 \sim 73 \%$ の値が得られた。

かまほこ，ハム，うぐいす豆，おはぎの場合: 各試 料に水を加えて 4 倍容のスラリーを作り, Ent A および C がそれぞれ $1.5 \mu \mathrm{g} / \mathrm{ml}$ になるよらに浱縮培養上清を 加え, $\mathrm{pH} 4.5$ ついで $\mathrm{pH} 6.0$ で遠心分離して沈殿を除 去し, 上清中の Ent 濃度を添加 Ent 濃度と比較した. その結果は Table 5 のとおりで，かまぼこ，ハムでは

Table 5. Recovered Enterotoxins $A$ and $C$ in the Supernatant Fluid of Food Slurry Prepared by Successive Centrifugations at $\mathrm{pH} 4.5$ and then at $\mathrm{pH} 6.0$

\begin{tabular}{|c|c|c|c|}
\hline \multirow{2}{*}{ Food } & \multirow{2}{*}{$\begin{array}{c}\text { Maker \& } \\
\text { Brand }\end{array}$} & \multicolumn{2}{|c|}{ Recovery rate (\%) } \\
\hline & & $\begin{array}{c}\text { Enterotoxin } \\
\mathrm{A}\end{array}$ & $\begin{array}{c}\text { Enterotoxin } \\
\mathrm{C}\end{array}$ \\
\hline \multirow{2}{*}{$\begin{array}{l}\text { KAMA- } \\
\text { BOKO }\end{array}$} & H-YAKI & 100 & $\geqq 60$ \\
\hline & $\mathrm{K}-\mathrm{AJI}$ & 100 & 100 \\
\hline $\begin{array}{l}\text { Pressed } \\
\text { ham }\end{array}$ & $\mathrm{I}-2$ & 100 & 100 \\
\hline \multirow{4}{*}{$\begin{array}{l}\text { UGUISU- } \\
\text { MAME }\end{array}$} & $\mathrm{H}$, in bulk & $<17$ & $<10$ \\
\hline & $\mathrm{A}, \quad "$ & $<17$ & $<10$ \\
\hline & $\begin{array}{l}\mathrm{K} \text {, vacuum } \\
\text { packed }\end{array}$ & $<17$ & $<10$ \\
\hline & $\mathrm{T}, \quad$ & $<17$ & $<10$ \\
\hline OHAGI* & $\mathbf{M}$ & $<17$ & $<10$ \\
\hline
\end{tabular}

* A rice cake covered with bean paste 
前回の実験成績と同様，遠心処理後の上清は対照と美が 認められなかった。一方，らぐいす豆およびおはぎでは 著明な減少が認められ，Ent A および C の残留濃度は それぞれ対照の 17 および 10\% 以下゙の成䅡が得られた。

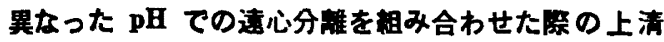
の Ent 漕度

シュークリーム，5ぐいす豆，おはぎ，おにぎり，ご はん等に水を加えて 4 倍容のスラリーを作り, Ent A お よび B が $3 \mu \mathrm{g} / \mathrm{ml}$ になるように浱縮培着上清を加え， $\mathrm{pH} 7.5$ で遠心分離した上清, $\mathrm{pH} 7.5$ の遠心分離上清を さらにpH 6.0 で遠心分離した上清, $\mathrm{pH} 7.5$ の遠心分離 上清を $\mathrm{pH} 4.5$ ついで $\mathrm{pH} 6.0$ で遠心分離して沈殿物を 除去した上清, ならびにスラリーを直接 $\mathrm{pH} 4.5$ ついで $\mathrm{pH}$ 6.0に䒨正して沈䟝物を除去した上清の 4 種を作り， Entの残留港度を測定して当初の添加濃度と比較した.そ の結果は Table 6 のとおりで, 款類食品では概して Ent の共沈する傾向が強かった。すすなわち，うぐいす豆では 直接 $\mathrm{pH} 4.5$ に修正して遠心分離すると残留率50\%以下 となるが，あらかじめ $\mathrm{pH} 7.4$ で食品不溶物を除いてお くと $\mathrm{pH} 4.5$ および $\mathrm{pH} 6.0$ で遠心分離しても残留率 100 \%の成績が得られた。 おはぎでは $\mathrm{pH} 4.5$ で遠心分離 するとあらかじめ $\mathrm{pH} 7.4$ で不溶物を除去しておいても 残留率 $50 \%$ 以下となるが，pH 7.5 で不溶物を遠心除去 した上清を $\mathrm{pH} 6.0$ に修正して遠心分離した上清の Ent 残留率は $100 \%$ を示した.この上清は低温で次第に沈殿

Table 6. Recovered Eenterotoxins A and B in the Supernatant Fluid of Food Slurry Prepared by Successive Centrifugations at Various $\mathrm{pH}$ Values

\begin{tabular}{|c|c|c|c|}
\hline \multirow{2}{*}{ Food } & \multirow{2}{*}{$\begin{array}{l}\text { Centrifuged } \\
\text { at } \mathrm{pH}\end{array}$} & \multicolumn{2}{|c|}{ Recovery rate (\%) } \\
\hline & & $\begin{array}{c}\text { Enterotoxin } \\
\mathrm{A}\end{array}$ & $\begin{array}{c}\text { Enterotoxin } \\
\mathrm{B} \\
\end{array}$ \\
\hline $\begin{array}{l}\text { Cream } \\
\text { puff } \\
\text { (Whole, A) }\end{array}$ & $\begin{array}{c}7.5 \\
7.5-6.0 \\
7.4-4.5-6.0 \\
4.5-6.0\end{array}$ & $\begin{array}{r}\geqq 90 \\
100 \\
100 \\
100\end{array}$ & $\begin{array}{r}100 \\
100 \\
100 \\
87,100\end{array}$ \\
\hline $\begin{array}{l}\text { UGUISU- } \\
\text { MAME } \\
\text { (A) }\end{array}$ & $\begin{array}{c}7.4-6.0 \\
7.4-4.5-6,0 \\
4.5-6.0\end{array}$ & $\begin{array}{r}100 \\
100 \\
<50\end{array}$ & $\begin{array}{r}100 \\
100 \\
<30\end{array}$ \\
\hline OHAGI (M) & $\begin{array}{c}7.5 \\
7.5-6.0 \\
7.4-4.5-6.0 \\
4.5-6.0\end{array}$ & $\begin{array}{c}100 \\
100 \rightarrow<56 \\
<50 \\
<50\end{array}$ & $\begin{array}{c}100 \\
100 \rightarrow<60 \\
<30 \\
<30\end{array}$ \\
\hline ONIGIRI*1 & $\begin{array}{c}7.5 \\
7.5-6.0\end{array}$ & $\begin{array}{l}100 \\
100\end{array}$ & $\begin{array}{l}100 \\
100\end{array}$ \\
\hline Rice & $\begin{array}{c}7.5 \\
7.5-6.0 \\
4.5-6.0\end{array}$ & $\begin{array}{l}<75^{* 2} \\
<75^{* 2}\end{array}$ & $\begin{array}{l}<89 \\
<89 \\
<\quad 89\end{array}$ \\
\hline
\end{tabular}

*1 Slightly salted rice ball

*2 Enterotoxin $\mathrm{C}$ was used
を生じ，Entはこれに吸着され，その上澄の Ent 濃度 は添加浱度の $60 \%$ 以下を示寸に至るが,これを $\mathrm{pH} 7.5$ に修正すると Ent は溶離し, 上澄の Ent 濃度の復元 が認められた。ごはんでは $\mathrm{pH} 7.5 て ゙$ 遠心分離しても上 清の Ent 榩度の減少が認められ，残留率 $89 \%$ 以下の 成績が得られたが，おにぎりでは減少が認められず， pH 7.5 および $\mathrm{pH} 6.0$ で遠心分漓して沈殿を除去した 上清中の Ent 残留率は $100 \%$ を示した。 この両者の成 績の差は試料中の 食塩の有無によることは明 らかであ る. また, この実験においてもシュークリームでは共沈 は認められなかった。

食中毒推定原因食品ならびに容疑食品の Ent 抽出試

\section{験成績}

Table 7 (I), (II) は動物質食品および動物質に富む食 品で, Table 8 は款類食品で，それぞれ実施した成績を 表にまとめたものである。この実験でも，実施条件の影 嘈を知るために, 食品の不溶物の除去は種々の $\mathrm{pH}$ の組 合せで行なった。 CMS の使用量は前述の酸処理上清で の実験で求められた Ent をほぼ完全に回収するに必要 な最少量とした，一部の実験では。この使用量の適否を 再確認するため, CMS で吸着後の廃液と洗液をプール し，これに新しいCMS を加えて未吸着の Ent を捕集 し，検出を試みたものもある，同表には，検出 Ent の 型と量のほか, スラリーの製法, スラリーに食塩を添加 して抽出を進めたものはイオン交換前のイオン濃度の引 き下げの方法, 供試食品の菌数と分離菌の Ent 産生能 等も付記しておいた。

事件別, 食品別の Ent 検出数: シュークリームでは 5 件中 2 件が $\mathrm{A}$ 型, 1 件が $\mathrm{AD}$ 型, 1 件が $\mathrm{AB}$ 型であ った. 不検出の 1 件は, 1 例の湢吐, 下琍患者の申し出 により調査したものであるが，容疑食品として供試した 患者の食い残し，ならびに同時製造の店頭陳列品にはブ ドウ球菌は検出されず，また他に同様な患者の発生も見 なかった。焼き魚 1 件は $\mathrm{AD}$ 型であり，つみれ 1 件は Ent, ブドゥ球菌とも検出されなかった。このつみれは 神奈川県衛生研究所よりブドウ球菌不検出の容疑食品と して分与されたるのである. 畉焼 1 件はA型であった。 すし玉 1 件は, Ent antiserum A で沈降反応を認めた が, reference line と典型的な coalescence を示さず, Ent 不検出と判定された。 また，この試料の分離ブドウ 球菌は Ent A-D 非産生であった。お扎ぎり 2 件は $\mathrm{AD}$ 型および AC 型, のりまき 1 件は $\mathrm{A}$ 型,ひがんだんご 2 件中 1 件はA型, 他の 1 件は Ent 不検出であった。 こ の不検出の検体は横兵市衛生研究所より容疑食品として 分与されたもので, Ent 産生ブドウ球菌も検出されなか

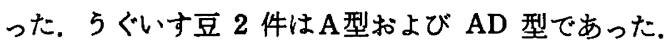

Ent 検出瀑度: 定量試験で検出した食中毒原因食品 の Ent 含有濃度は，僅微なむのから $0.3 \mu \mathrm{g} / \mathrm{g}$ のもの までまちまちであったが，その平均値は大約 $0.05 \mu \mathrm{g} / \mathrm{g}$ 
Table 7. Detection of Enterotoxins in Foods Involved in Food Poisoning Outbreaks

(I)

\begin{tabular}{|c|c|c|c|c|c|c|c|}
\hline Outbreak & Sample & $\begin{array}{l}\text { Slurry-fold } \\
\text { dilution }\end{array}$ & $\begin{array}{c}\text { Centrifuged } \\
\text { at } \mathrm{pH}\end{array}$ & $\left|\begin{array}{c}m l \text { of super- } \\
\text { natant } \mathrm{fl} . / \mathrm{g} \\
\text { of CM- } \\
\text { Sephadex }\end{array}\right|$ & $\begin{array}{l}\text { Con- } \\
\text { centration } \\
\text {-fold }\end{array}$ & $\begin{array}{c}\text { Detected } \\
\text { entero- } \\
\text { toxin } \\
\mu \mathrm{g} / \mathrm{g}\end{array}$ & $\begin{array}{l}\text { Staphylo- } \\
\text { cocci/g \& } \\
\text { Produced } \\
\text { enterotoxin }\end{array}$ \\
\hline $\begin{array}{l}\text { Sept., } 1968 \\
\text { KOBE C. }\end{array}$ & $\begin{array}{l}\text { Cream puff } \\
\text { (Cream) }\end{array}$ & 4 & $4.5-6.0$ & $\begin{array}{c}240 \\
\text { Effuent } 960\end{array}$ & $\begin{array}{r}50 \\
150 \\
\end{array}$ & $\mathrm{~A}(0.04)$ & $\begin{array}{c}4 \times 10^{7} \\
\mathrm{AD}\end{array}$ \\
\hline $\begin{array}{l}\text { Feb., } 1969 \\
\text { KOBE C. }\end{array}$ & $\begin{array}{l}\text { Cream puff } \\
\text { (Cream, } \\
\text { Patient) } \\
\text { (Cream, } \\
\text { Shop) } \\
\end{array}$ & $\cdots$ & $\begin{array}{c}4.5-6.0 \\
\quad n\end{array}$ & $\begin{array}{c}200 \\
n\end{array}$ & $\begin{array}{l}32 \\
46\end{array}$ & - & $\begin{array}{l}<10^{2} \\
<10^{2}\end{array}$ \\
\hline $\begin{array}{l}\text { June, } 1969 \\
\text { KOBE C. }\end{array}$ & $\begin{array}{l}\text { Cream puff } \\
\text { (Cream) }\end{array}$ & 4 & $4.5-6.0$ & 200 & 72 & $\begin{array}{l}\mathrm{A}(0.3) \\
\mathrm{B}(0.01)\end{array}$ & $\begin{array}{c}4 \times 10^{6} \\
- \\
\text { (two strains) } \\
\end{array}$ \\
\hline $\begin{array}{l}1970 \\
\text { YOKOHAMA } \\
\text { C. }\end{array}$ & $\begin{array}{l}\text { Cream puff } \\
\text { (Whole) }\end{array}$ & 10 & $\begin{array}{c}7.4-4.5-6.0 \\
4.5-6.0\end{array}$ & $\begin{array}{l}586 \\
580\end{array}$ & $\begin{array}{l}>19 \\
>27\end{array}$ & A B & $\begin{array}{c}52 \times 10^{2} \\
-\end{array}$ \\
\hline $\begin{array}{l}\text { Oct., } 1971 \\
\text { KANAGAWA } \\
\text { Pref. }\end{array}$ & $\begin{array}{c}\text { Cream puff } \\
\text { (1, Whole) } \\
" \\
" \\
\text { (2, Whole) } \\
\text { (3, Cream) } \\
(3, \text { Whole) } \\
" \\
(4, \text { Whole }) \\
" \\
"\end{array}$ & $\begin{array}{c}4 \\
" \prime \\
\text { " } \\
4(0.2 \mathrm{M} \mathrm{NaCl}) \\
8(0.2 \mathrm{M} \text { } \mathrm{NaCl}) \\
4 \\
4 \\
" \prime \\
\text { " } \\
8(0.2 \mathrm{M} \mathrm{NaCl}) \\
4 \\
4(0.2 \mathrm{M} \mathrm{NaCl})\end{array}$ & $\begin{array}{c}4.5-6.0 \\
7.6-4.5-6.0 \\
7.6-6.0 \\
" 7.5-6.0 \\
7.6-4.6-6.0 \\
7.6-6.0 \\
7.5-6.0 \\
4.5-6.0 \\
7.5-6.0 \\
4.5-6.0 \\
7.5-6.0 \\
7.5-6.0 \\
4.5-6.0 \\
7.5-6.0\end{array}$ & $\begin{array}{c}240 \\
" \\
" \\
" * 2 \\
480 * 2 \\
n * 2 \\
200 \\
" \\
" \\
" * 1 \\
\text { Effluent200*1 } \\
240 \\
" * * 2 \\
" * 2\end{array}$ & $\begin{array}{l}>18 \\
>25 \\
>25 \\
>19 \\
>19 \\
>25 \\
72 \\
78 \\
78 \\
71 \\
101 \\
67 \\
59.7 \\
51.4 \\
50.8\end{array}$ & $\begin{array}{c}A(+) \\
A( \pm) \\
A(H) \\
A(+) \\
A(H) \\
A(H) \\
A \cdot(0.02) \\
A(0.02) \\
A(0.015) \\
A(0.015) \\
A(0.004) \\
A( \pm) \\
A(0.03) \\
A(0.03) \\
A(0.03)\end{array}$ & $\begin{array}{c}10^{8} \\
\mathrm{~A} \mathrm{~B} \\
\text { (one strain) }\end{array}$ \\
\hline
\end{tabular}

*1 Ionic strength was lowered by dilution with $0.005 \mathrm{M}$ sodium phosphate ( $\mathrm{pH} 6.0$ ).

*2 Ionic strength was lowered by dialysis against tap water.

-: enterotoxin not detected $\pm,+, H, H$ : very faint, faint, medium or heavy lines of precipitation, respectively

(II)

\begin{tabular}{|c|c|c|c|c|c|c|c|}
\hline Outbreak & Sample & $\begin{array}{c}\text { Slurry -fold } \\
\text { dilution }\end{array}$ & $\begin{array}{l}\text { Centrifuged } \\
\text { at } \mathrm{pH}\end{array}$ & $\begin{array}{c}\text { ml of super- } \\
\text { natant } f . / 9 \\
\text { of } \mathrm{CM}- \\
\text { Sephadex } \\
\end{array}$ & $\begin{array}{l}\text { Con- } \\
\text { centration } \\
\quad \text {-fold }\end{array}$ & $\begin{array}{c}\text { Detected } \\
\text { entero- } \\
\text { toxin } \\
\mu \mathrm{g} / \mathrm{g}\end{array}$ & $\begin{array}{l}\text { Staphylo- } \\
\text { cocci/g \& } \\
\text { Prduced } \\
\text { enterotoxin }\end{array}$ \\
\hline $\begin{array}{l}\text { June, } 1969 \\
\text { OSAKA Pref. }\end{array}$ & Roasted fish & 4 & $4.5-6.0$ & $\begin{array}{c}120 \\
\text { Effluent } 240\end{array}$ & $\begin{array}{r}>41 \\
41\end{array}$ & $\begin{array}{l}\mathrm{A}(<0.07) \\
\mathrm{D}(0.09)\end{array}$ & $\begin{array}{c}10^{8} \\
A \text { (one strain) }\end{array}$ \\
\hline $\begin{array}{l}\text { Sept., } 1969 \\
\text { KANAGAWA } \\
\text { Pref. }\end{array}$ & TSUMIRE*1 & 5 & $4.5-6.0$ & $\begin{array}{c}150 \\
\text { Effluent } 510\end{array}$ & $\begin{array}{r}88 \\
142\end{array}$ & - & $<10^{2}$ \\
\hline $\begin{array}{l}\text { May, } 1971 \\
\text { KANAGAWA } \\
\text { Pref. }\end{array}$ & $\begin{array}{l}\text { TAMAGO } \\
\text { YAKI*2 }\end{array}$ & 5 & $4.5-6.0$ & 125 & 30 & $\mathrm{~A}(0.01)$ & $\begin{array}{r}10^{8} \\
\mathrm{AD}\end{array}$ \\
\hline $\begin{array}{l}\text { Dec., } 1971 \\
\text { YOKOHAMA } \\
\text { C. }\end{array}$ & SUSITAMA $* 3$ & $\begin{array}{c}4(0.2 \mathrm{M} \mathrm{NaCl}) \\
4(0.2 \mathrm{M} \mathrm{NaCl}) \\
4 \\
4\end{array}$ & $\begin{array}{r}7.5-6.0 \\
7.5-6.0 \\
4.5-6.0 \\
4.5-6.0\end{array}$ & $\begin{array}{c}120 \\
\text { Effluent } 120 \\
120 \\
\text { Effuent } 120 \\
120 \\
\text { Effluent } 120 \\
120\end{array}$ & $\begin{array}{r}92 \\
85 \\
79 \\
101 \\
81 \\
85 \\
75\end{array}$ & $\begin{array}{l}- \\
= \\
= \\
=\end{array}$ & $98 \times 10^{7}$ \\
\hline
\end{tabular}

*1 Japanese-style soft fish cake

*2 Fried egg *s Sour egg cake

-: Enterotoxin not detected 
Table 8. Detection of Enterotoxins in Foods Involved in Food Poisoning Outbreaks

\begin{tabular}{|c|c|c|c|c|c|c|c|}
\hline Outbreak & Sample & $\begin{array}{l}\text { Slurry -fold } \\
\text { dilution }\end{array}$ & at $\begin{array}{c}\text { Centrifuged } \\
\text { at }\end{array}$ & $\begin{array}{c}\mathrm{ml} \text { of super- } \\
\text { natant } \mathrm{fl} / \mathrm{g} \\
\text { of CM- } \\
\text { Sephadex }\end{array}$ & $\begin{array}{l}\text { Con- } \\
\text { centration } \\
\quad \text {-fold }\end{array}$ & $\begin{array}{c}\text { Detected } \\
\text { entero- } \\
\text { toxin } \\
\mu \mathrm{g} / \mathrm{g}\end{array}$ & $\begin{array}{l}\text { Staphylo- } \\
\text { cocci/g \& } \\
\text { Produced } \\
\text { enterotoxin }\end{array}$ \\
\hline $\begin{array}{l}\text { July, } 1969 \\
\text { KANAGAWA } \\
\text { Pref. }\end{array}$ & ONIGIRI & 5 (mashed) & $\begin{array}{l}(7.4)-4.5- \\
6.0^{-}\end{array}$ & $\begin{array}{c}300 \\
\text { Effluent } 300\end{array}$ & $\begin{array}{r}46 \\
107\end{array}$ & $\begin{array}{l}\mathrm{A}(0.05) \\
\mathrm{D}(0.035)\end{array}$ & $\begin{array}{r}5 \times 10^{8} \\
\mathrm{AD}, \mathrm{A}\end{array}$ \\
\hline $\begin{array}{l}\text { Aug., } 1969 \\
\text { KANAGAWA } \\
\text { Pref. }\end{array}$ & ONIGIRI & 5 (mashed) & $\begin{array}{l}(7.4)-4.5- \\
6.0^{-1}\end{array}$ & $\begin{array}{c}300 \\
\text { Effluent } 300\end{array}$ & $\begin{array}{r}69 \\
121\end{array}$ & $\stackrel{\text { A C }}{-}$ & $\begin{array}{l}3 \times 10^{8} \\
\mathrm{ABC}\end{array}$ \\
\hline $\begin{array}{l}\text { Sept., } 1970 \\
\text { YOKOHAMA } \\
\text { C. } \\
\end{array}$ & NORIMAKI*1 & ${ }^{10}$ & $\begin{array}{c}7.4-4.5 \\
4.5\end{array}$ & $\begin{array}{c}463 \\
489 \\
\text { Effluent } 897\end{array}$ & $\begin{array}{l}47 \\
58 \\
88\end{array}$ & $\begin{array}{c}\mathrm{A}(0.01) \\
=\end{array}$ & $\begin{array}{c}<30 \times 10^{2} \\
-\end{array}$ \\
\hline $\begin{array}{l}\text { Sept., } 1970 \\
\text { YOKOHAMA } \\
\text { C. }\end{array}$ & $\begin{array}{l}\text { HIGAN- } \\
\text { DANGO*2 } \\
\text { (Patient) } \\
\text { (Shop) } \\
" \prime\end{array}$ & $\begin{array}{c}10 \\
8 \\
n \\
5\end{array}$ & \begin{tabular}{|c|}
$4.5-6.0$ \\
$7.4-4.5-6.0$ \\
$4.5-6.0$ \\
7.4
\end{tabular} & $\begin{array}{c}583 \\
447 \\
449 \\
\text { Effluent } 898 \\
250 \\
\text { Effluent } 1200\end{array}$ & $\begin{array}{r}60 \\
40 \\
80 \\
55 \\
>82 \\
290\end{array}$ & $\begin{array}{c}\mathrm{A}( \pm) \\
\overline{-} \\
\bar{A}\end{array}$ & $\begin{array}{l}8 \times 10^{7} \mathrm{AD} \\
6 \times 10^{8} \mathrm{AD}\end{array}$ \\
\hline $\begin{array}{l}1971 \\
\text { YOKOHAMA } \\
\text { C. }\end{array}$ & $\begin{array}{l}\text { HIGAN- } \\
\text { DANGO*2 }\end{array}$ & 5 & 7.5 & 250 & 70 & - & $\begin{array}{l}10^{7}, \text { molded } \\
-(9 \text { strains })\end{array}$ \\
\hline $\begin{array}{l}\text { Sept., } 1968 \\
\text { OSAKA Pref. }\end{array}$ & $\begin{array}{l}\text { UGUISU- } \\
\text { MAME } \\
\text { (Patient) } \\
\text { (Shop) }\end{array}$ & $\begin{array}{l}\text { 4(mashed) } \\
\text { 4(mashed) }\end{array}$ & $\begin{array}{l}(7.4)-4.5 \\
(7.4)-4.5\end{array}$ & $\begin{array}{c}240 \\
\text { Effluent } 960 \\
200\end{array}$ & $\begin{array}{r}42 \\
68 \\
108\end{array}$ & $\begin{array}{l}\mathrm{A}(0.06) \\
\mathrm{A}(0.01) \\
\mathrm{A}(0.005)\end{array}$ & $\begin{array}{l}3 \times 10^{8} \mathrm{~A} \\
9 \times 10^{4}\end{array}$ \\
\hline $\begin{array}{l}\text { May, } 1971 \\
\text { KANAGAWA } \\
\text { Pref. }\end{array}$ & 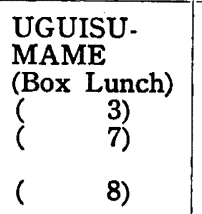 & $\begin{array}{l}5 \\
4 \\
5 \\
4\end{array}$ & $\begin{array}{l}4.5 \\
4.5 \\
4.5 \\
4.5\end{array}$ & $\begin{array}{l}221 \\
197 \\
226 \\
\\
189\end{array}$ & $\begin{array}{r}23 \\
>49 \\
60 \\
> \\
>\end{array}$ & $\begin{array}{c}\mathrm{A}(0.013) \\
\mathrm{A} \\
\mathrm{A}(0.008) \\
\mathrm{D}(0.01) \\
\mathrm{A}\end{array}$ & $\begin{array}{c}10^{8}-10^{9} \\
\mathrm{AD}\end{array}$ \\
\hline
\end{tabular}

*1 seasoned rice rolled in layer *2 A rice cake covered with bean paste

-: enterotoxin not detected $( \pm)$ : very faint line of precipitation

であった。

CMS 処理廃液中の Ent 残存: CMS 処理廃液に残存 する Ent の再捕集実験では， らぐいす豆での 1 例に総 量の約 1/7 の Ent の残存を認めたが, この検体は供試 時やや乾燥していた，その他の例では忹とんど残存を認 めなかった。

抽出物の毒性：食中書原因食品の本法抽出物の 毒性 については, 1971 年 10 月関東一円に多数の患者を出し たベビーシュークリームを用いて試験した。供試された Table 7 (I) 下端に記載のシュークリーム No. 4 は 0.03 $\mu \mathrm{g} / \mathrm{g}$ の Ent A が検出されたが,この試料 $150 \mathrm{~g}$ 分に 相当し, Ent A $4.5 \mu \mathrm{g}$ の含有が確認された抽出物を流 水で 3 時間透析後, 牛乳 $180 \mathrm{ml}$ とともに成人 1 名が领 用した。 その結果, 搵取 3 時間 40 分後より頭痛, 悪心 を起し, 時とともに次第にその強さを增し, 時折軽い哐
気を催し， 4 時間 25 分後 3 回激しく湢吐した。 その後, 頭痛は急速に軽痹したが， 8 時間 20 分後軟便を排し, 9 時間 20 分後水様の下浰を起した。

\section{考寀}

食品中の Ent を抽出するに際して特に留意すべきこ とは，イオン交換体の使用量が不足して Ent の回收率 が激減することである。これは陚料中に多量に含まれる 食品成分によるものであるが，この傾向は一般に動物性 食品に強く, 䟬類食品に弱い, 本研究では, この減収を 避けるために必要な CMS の最低の使用量を食品別に明 らかにした。

これと同様に Ent の回収率を大きく左右する因子と して食品の不溶物を遠心除去する際に起る共沈現象があ る.この対策として Casman $5^{16)}$ は $0.2 \mathrm{M}$ 食塩水で 食品中の Ent を抽出することにしたが，その後の処理 
を簡略にするためでさるだけ水で抽出することにし，共 沈を回避できない場合に限り加塩する方が得策と考え る.

すなわち，穀類食品の場合は概して共沈が起こりやす く，特別な配虑を要するが，動物質食品および動物質に 富む食品では蒸留水でスラリーを作ってもほとんど支障 は認められない。

さらに，殼類食品に蒸留水を加えてスラリーを作った 場合でも，ごはんは例外であるが，通常食中毒が多発す るおにぎり，おはぎ，5ぐいす豆では，pH 7.5 で遠心 分離して沈殿を除去し，ついで $\mathrm{pH} 6.0$ で遠心分離して 得た上清を直ちにイオン交換に付するようにするか，冷 蔵中に析出した沈殿を $\mathrm{pH} 7.5$ て除去するよ5にすれば， この間における共沈は避けられるよらである.

食中毒原因の疑いがかけられた穀類食品で行なった実 験 (Table 8)のらち，ホモジナイザーでスラリーを作製 して抽出を進めた例は，概して微弱な Ent しか検出さ れていない。もしこれが共沈の影隦であるのなら，前述 の方途により解決されると思う。一方，試料を乳鉢で磨 确して抽出を進めた例は, 検出 Ent 量が大きく, 動物 性食品の成績 (Table 7) と差がなかったので，穀類食品 は, ホモジナイザーで処理するより, 凍結保存などによ ってデンプンを $\beta$ 化し，乳鉢ですりつぶして溶出する方 が無難と考えている.

食中毒事件由来の供試食品の事件別 Ent 検出数は，A 型 6 件, $\mathrm{AD}$ 型 4 件, $\mathrm{AC}$ 型 1 件, $\mathrm{AB}$ 型 1 件で, $\mathrm{A}$ 型 と $\mathrm{AD}$ 型で大部分を占めていた。この割合は，Casman ${ }^{191}$ ， Šimokovičová $5^{201}$, 寺山21), Burbianka ${ }^{22)}$ が食中毒事 件例の分離ブドウ球菌で調查した Ent 型別成績とほぼ 一致している.

これに比し, 事件別の Ent 産生ブドウ球菌の検出数 は, $\mathrm{A}$ 型 2 件, $\mathrm{AD}$ 型 5 件, $\mathrm{ABC}$ 型 1 件, $\mathrm{AB}$ 型 1 件 でかなりの差があり, Ent 産生ブドウ球菌検出率 (56 \%）は食品の Ent 検出率 $(75 \%)$ より低かった。これは 菌梌索を従とし，かなり遅れて菌分離を試みたことが主 因と思らが,ブドウ球菌の検出にたよる食中毒原因の追 求が原因菌の食品中での宿命的な消隇や他種菌との競 合, その他の原因で失敗に終りやすいことを側面的に示 しているものと思 5.

抽出条件の模索や良否の確認を同時に試みるため, 本 研究に批る Ent の抽出はまちまちの方法がとられ, 必ずしも最良の条件で行なわれてはいないが，定量的に 検出した食中毒原因食品の Ent 濃度は, 最高 $0.3 \mu \mathrm{g} / \mathrm{g}$ で, 平均 $0.05 \mu \mathrm{g} / \mathrm{g}$ であった。

Casman ら4) は, ブドウ球菌のブレインハートインフ ュージョンブイョン曝気培㽰に推ける菌数と Ent A の 産生量との関係がそのまま成り立つなら，通常の食中毒 原因食に含まれる Ent 濃度は $0.01 \sim 0.04 \mu \mathrm{g} / \mathrm{g}$ になる と述べている．またブドウ球菌を種々の食品に接種して
Ent A の産生量を測定しているが，この成績より同様に 推論すれば, 菌数 $10^{8} / \mathrm{g}$ 台の通常の食中毒原因食に含ま れる Ent 瀑度は 0.02 0.12 $\mu \mathrm{g} / \mathrm{g}$ といらことになる。 また，Zehren ら5)は食中畫原因となったチーズに 0.12 $\mu \mathrm{g} / \mathrm{g}$ の Ent A を検出している. 本研究に猢る Ent 実測值は,これらの推測值や業績と大差なかった。

検出 Ent 濃度の病因上の意義は食品の摄取量との関 連で決るが，本研究で $0.03 \mu \mathrm{g} / \mathrm{g}$ 検出し，総量 $4.5 \mu \mathrm{g}$ の Ent A を含むことが判明した食中毒原因シュークリ ーム $150 \mathrm{~g}$, すなわら普通サイズのシュークリーム 2 個 半分の抽出物の摂取で，ヒトに典型的な Ent 中毒症状 を起こし得たことは，これらの測定値のレベルが実際に 発症と結びっくことを示すものと教える.

ヒトの Ent での発症量については, 従来一般に低く 見積られ 15 20 $\mu \mathrm{g}$ と考えられていたが，Zehren ら5 は $0.12 \mu \mathrm{g} / \mathrm{g}$ の Ent A を検出したチーズ $60 \mathrm{~g}$ を摄取 して 4 人中 2 人が嘔吐したことを報告し，大約 $7.2 \mu \mathrm{g}$ で発症することを暗示した．著者はさらに少量の $4.5 \mu \mathrm{g}$ で発症することを明らかにした。

結論

1. 食品に蒸留水を加えホモジナイズ（款類食品では 乳鉢で磨碎)して pH 7.4 7.6 でかく拌し，その遠心 分離上清を動物質食品では $\mathrm{pH} 4.5$ および $\mathrm{pH} 6.0$ で, 款類食品では $\mathrm{pH} 6.0$ で, それぞれ遠心分離して沈股を 除去し, CMS でバッチ法により Entを吸着, 捕集し, 洗浄, 溶出後, polyethyleneglycol で濃縮する方法によ り，広範囲の食品から Ent を抽出できる。これを抗原 として micro-Ouchterlony 法ゲル内沈降反応により Ent を検出した。

この抽出に必要な CMS 量を食品別に決定した。

2. 食中書事件 16 例のらち 12 例の供試食品に Ent を検出したが，その型は A および AD で 83\%を占め た。検出 Ent 濃度は最高 $0.3 \mu \mathrm{g} / \mathrm{g}$, 平均 $0.05 \mu \mathrm{g} / \mathrm{g}$ で あった。

不検出の 4 例の試料には, ブドウ球菌または Ent 産 生ブドウ球菌を検出しなかった。

3. 食中韵原因シュークリームの本法抽出物でEnt A を $4.5 \mu \mathrm{g}$ 含有する試料を, 1 例のヒトに飲用させたと ころ, 典型的な Ent 中毒症状を起こした。

稿を終るに臨み, 貴重な抗血清および reference toxin の分与を賜わった米国 FDA の故 E. P. Casman博士拉 よび Research Microbiologist R. W. Bennett 氏, な らびに米国 Wisconsin 大学教授 M.S. Bergdoll 博士 に深甚なる謝意を表します，なお，本報の成綪は昭和44 年11月13日第24回日本細菌学会関東支部総会および昭和 47 年 5 月 20 日第45回日本細菌学会総会で発表した。

文献

1) Hall, H. E., Angelotti, R., Lewis, K. H.: Pub. Health Rep. 78, 1089 (1963). 
2) Hall, H. E., Angelotti, R., Lewis, K. H.: Health Lab. Sci. 2, 179 (1965).

3) Casman, E. P., McCoy, D. W., Brandly, P. J.: Appl. Microbiol. 11, 498 (1963).

4) Casman, E. P., Bennett, R. W.: ibid. 13, 181 (1965).

5) Zehren, V. L., Zehren, F.: J. Dairy Sci. 48, 411 (1965).

6) 国田信治，加藤亮哿，中原正良，品川牛汎，阪口 玄二：食衛誌. 13， 223 (1972).

7) Casman, E. P.: Health Lab. Sci. 4, 199 (1967).

8) Casman, E. P.: FDA Pap. 3, 15 (1969).

9）原田禎顕：長崎医会誌。38, 807 (1963).

10）原田禎顕：同上. 38, 835 (1963).

11) 原田禎顕：同上. 39, 827 (1964).

12）原田禎穎：同上. 43,473 (1968).

13) Hallander, H. O.: Acta Pathol. Microbiol.
Scand. 63, 299 (1965).

14) Jarvis, A. W., Lawrence, R. C.: Appl. Microbiol. 19, 698 (1970).

15) Crowle, A. J.: J. Lab. Clin. Med. 52, 784 (1958).

16) Casman, E. P., Bennett, R. W., Dorsey, A. E.: Health Lab. Sci. 6, 185 (1969).

17) Read, R. B., Pritchard, W. L., Bradshaw, J., Black, L. A.: J. Dairy Sci. 48, 411 (1965).

18) Casman, E. P., Bennett, R. W.: J. Bacteriol. 86, 18 (1963).

19) Casman, E. P.: Ann. N. Y. Acad. Sci. 128, 124 (1965).

20) Šimokovičová, M., Gilbert, R. J.: J. Med. Microbiol. 4, 19 (1971).

21) 寺山 武: 日本細菌学雑誌 26, 611 (1971).

22) Burbianka, M.: Przegl. Epidemiol. 25, 257 (1971). 